\title{
Clinical, electrocardiographic, and haemodynamic effects of digitalis (ouabain) in angina pectoris
}

\author{
B. Sharma, P. A. Majid, M. K. Meeran, W. Whitaker, and S. H. Taylor \\ From the Cardiovascular Unit, University Department of Medicine, The General Infirmary, \\ Leeds
}

The symptomatic, electrocardiographic, and haemodynamic effects of acute digitalization with ouabain were studied in 6 male patients with uncomplicated angina pectoris. Ouabain improved the depressed left ventricular function associated with the onset of pain in all patients, without aggravation of their symptoms or further deterioration in the electrocardiogram. It is suggested that the reduction in myocardial oxygen consumption resulting from improvement in left ventricular function after the drug probably masks any increase due to its positive inotropic activities. The digitalis glycosides may therefore have a place in the treatment of angina, particularly when used in conjunction with the adrenergic beta-blocking drugs.

The onset of pain during exercise in patients with angina pectoris is consistently associated with clinical and haemodynamic signs of acute left ventricular failure (Muller and Rorvik, 1958; Dimond and Benchimol, 1963; Messer et al., 1963; Malmborg, 1965; Cohen et al., 1965; Parker, Di Giorgi, and West, 1966; McCallister et al., 1968; Wiener, Dwyer, and Cox, 1968; Sharma and Taylor, 1970). A unique characteristic of this syndrome is its rapid reversibility, the raised end-diastolic pressure in the ventricle rapidly returning to normal when exercise is stopped (Taylor and Sharma, 197I). There is direct experimental evidence to suggest that depression of ventricular function due to ischaemia may be im-

* proved by the digitalis glycosides (Sarnoff et al., 1964). The symptomatic, electrocardiographic, and haemodynamic effects of acute digitalization with ouabain were therefore examined in patients with angina pectoris.

\section{Subjects and methods}

Six male patients, average age 55 years (range 49-62), with uncomplicated angina pectoris were studied. Their average weight was $74.4 \mathrm{~kg}$ (range 55-94) and their average surface area $\mathrm{r} \cdot 80 \mathrm{~m}^{2}$ (range $I \cdot 60-2 \cdot 12)$. None was obese, hypertensive, or diabetic, none had hyperlipidaemia, and none had had a previous myocardial infarction or his-

tory of other heart disease. In all, the angina was

Received 9 August 197 r. induced solely and repeatedly by exercise; none suffered from nocturnal or emotionally induced pain. The length of the history of angina ranged from 6 months to ro years. No patient had received previous treatment other than glyceryl trinitrate.

The resting electrocardiogram was normal in all patients; during supine leg exercise the ST segment in the standard and chest leads $\mathrm{V}_{4}-6$ was depressed by more than I $\mathrm{mm}$ in all patients. The standard 6 foot chest $x$-ray was normal and the cardiothoracic ratio was less than 50 per cent in all patients.

These studies were carried out during routine diagnostic haemodynamic investigation before angiographic studies in patients under consideration for coronary artery operation. The purpose, procedure, and possible therapeutic benefits of these additional studies were discussed with each patient; without inducement all freely consented to the additional observations (Medical Research Council, I964; Ormrod, 1968).

Design of investigation Each patient was trained to exercise in the supine position on a bicycle ergometer and to indicate by fingeroperated light switch the onset and the relative intensity of pain. The level of exercise required to induce angina during the first 2 or 3 minutes of the 6-minute exercise period was then ascertained. The pain was graded as 'mild' when there was a tightness and discomfort in the chest, 'moderate' when the pain was significantly greater in intensity but the patient was still able to continue exercise, and 'severe' when the pain was of such intensity that the patient was rapidly forced to stop exercise. 
The study started with a 6-minute period of supine leg exercise at constant speed and load followed by a 20-minute period of rest. Cardiac output was measured by the direct oxygen Fick method during the 5 th and 6th minutes of the exercise period and during the final 4 minutes of rest period.

Ouabain $0.01 \mathrm{mg} / \mathrm{kg}$ body weight was then injected into the pulmonary artery over a period of 30 seconds. This is the maximum recommended therapeutic dose (Goodman and Gilman, 1970). After 30 minutes, the time of maximum cardiac activity of the drug, the studies were repeated with a 4-minute rest period followed by a 6minute period of supine leg exercise at the same speed and load as previously. Cardiac output was again measured during the 4-minute rest period and during the final 2 minutes of the exercise period. Intravascular and intracardiac pressures and electrocardiogram were recorded continuously throughout the procedure.

Laboratory techniques Aortic and left ventricular pressures were measured through nylon catheters $(75 \times 0.1 \mathrm{~cm})$ introduced percutaneously from the brachial arteries (Seldinger method). Catheters were undamped and pressures were transduced by Statham P23Db strain-gauge manometers. The common zero reference level for all pressures was set $10 \mathrm{~cm}$ below the sternal angle with the patient supine. All manometers were calibrated against a common open column of saline over the range o-100 $\mathrm{mmHg}$ which was arranged to span $10 \mathrm{~cm}$ recording paper. Over this range the manometers were linear within 2 per cent. The first differential of the left ventricular pressure (dp/dt max) was obtained by a simple electronic differentiating circuit and calibrated by an oscillator. Two systemic arterial blood samples were taken from the aorta and four mixed venous blood samples from the pulmonary artery during each cardiac output estimation. Blood samples were analysed in duplicate for percentage oxygen saturation on a Kipp haemoreflector. The systemic arterial blood samples were also analysed in duplicate for oxygen-carrying capacity by spectral absorption of the haemolysed blood at two wave lengths. Expired air was collected, and respiratory rate and ventilatory volumes measured, in a Tissot spirometer. Expired air, and blood gas tensions, were measured by a direct polarographic method (Electronic Instrument Laboratories) calibrated by gases analysed on a Lloyd-Haldane apparatus. Using these methods under similar conditions of study to those of the present investigation, duplicate measurements of the cardiac output and intravascular pressures agreed to within 7 per cent both at rest and during exercise. The electrocardiograph was recorded with disc adhesive electrodes from chest lead V5. Intravascular pressures and electrocardiogram were recorded continuously on an ultraviolet light recorder (SE Model 30I2) using only the linear arc of traverse of the galvanometers.

Measurements, calculations, and statistical methods Mean pressures were measured from electronically integrated records over two whole respiratory cycles. The mean systolic pressure was measured by planimetric integration of the left ventricular pressure pulse over one respiratory cycle by a method described elsewhere (Taylor et al., 1967). Left ventricular work was calculated according to the method of Dexter et al. (195I). The ST depression in lead V 5 of the electrocardiograph was measured from the J-point to the isoelectric line joining two consecutive PR intervals. The ST area $(\Delta \mathrm{ST})$ was measured and converted into microvolt seconds (Sheffield et al., 1969).

Statistical analyses were based on orthodox methods (Fisher, 1946). The probability of significance of differences relates to comparison of paired samples.

\section{Results}

Symptoms In the control study the average time of onset of pain in the 6 patients was 1 I5 sec (range 65-190) after the start of exercise

TABLE Summary of statistical analysis

\begin{tabular}{|c|c|c|c|c|c|c|c|c|c|c|c|c|}
\hline \multirow[t]{3}{*}{ State } & & \multirow{3}{*}{$\begin{array}{l}\text { Respira- } \\
\text { tory } \\
\text { rate/min }\end{array}$} & \multirow{3}{*}{$\begin{array}{l}\text { Ventila- } \\
\text { tion } \\
(\text { l. } / \text { min } \\
\left.\text { per } m^{2}\right)\end{array}$} & \multirow{3}{*}{$\begin{array}{l}\text { Oxygen } \\
\text { uptake } \\
(\mathrm{ml} . / \mathrm{min} \\
\left.\text { per } \mathrm{m}^{2}\right)\end{array}$} & \multirow{3}{*}{$\begin{array}{l}\text { Heart } \\
\text { rate/min }\end{array}$} & \multirow{3}{*}{$\begin{array}{l}\text { Stroke } \\
\text { volume } \\
\left(\mathrm{ml} . / \mathrm{m}^{2}\right)\end{array}$} & \multicolumn{6}{|c|}{ Intravascular pressures $(\mathrm{mmHg})$} \\
\hline & & & & & & & \multirow{2}{*}{$\begin{array}{l}\text { Cardiac } \\
\text { output } \\
\text { (l./min } \\
\left.\text { per } m^{2}\right)\end{array}$} & \multicolumn{3}{|l|}{ Aortic } & \multicolumn{2}{|c|}{ Left ventricular } \\
\hline & & & & & & & & Systolic & Diastolic & Mean & $\begin{array}{l}\text { Mean } \\
\text { systolic }\end{array}$ & $\begin{array}{l}\text { End- } \\
\text { diastolic }\end{array}$ \\
\hline \multirow{2}{*}{ Rest } & $\int \begin{array}{l}\text { Before } \\
\text { ouabain }\end{array}$ & $\begin{array}{l}17 \pm I \\
(3)\end{array}$ & $\begin{array}{l}4 \cdot 6 \pm 0.2 \\
(0.4)\end{array}$ & $\begin{array}{l}132 \pm 6 \\
(14)\end{array}$ & $\begin{array}{l}83 \pm 5 \\
(12)\end{array}$ & $\begin{array}{l}33 \pm 3 \\
(7)\end{array}$ & $\begin{array}{l}2 \cdot 7 \pm 0.2 \\
(0.6)\end{array}$ & $\begin{array}{l}161 \pm 15 \\
(38)\end{array}$ & $\begin{array}{l}87 \pm 3 \\
(8)\end{array}$ & $\begin{array}{l}\operatorname{Irg} \pm 8 \\
\text { (I9) }\end{array}$ & $\begin{array}{l}I 43 \pm I I \\
(28)\end{array}$ & $\begin{array}{l}14 \pm I \\
(2)\end{array}$ \\
\hline & $\left\{\begin{array}{c}\text { After } \\
\text { ouabain }\end{array}\right.$ & $\begin{array}{l}17 \pm 1 \\
\text { (3) }\end{array}$ & $\begin{array}{l}4 \cdot 6 \pm 0.3 \\
(0.6)\end{array}$ & $\begin{array}{l}132 \pm 7 \\
(18)\end{array}$ & $\begin{array}{l}80 \pm 2 \\
(5)\end{array}$ & $\begin{array}{l}34 \pm 3 \\
(8)\end{array}$ & $\begin{array}{l}2 \cdot 7 \pm 0.2 \\
(0.6)\end{array}$ & $\begin{array}{l}163 \pm 16 \\
(39)\end{array}$ & $\begin{array}{l}85 \pm 4 \\
\text { (10) }\end{array}$ & $\begin{array}{l}\text { II } 19 \pm 8 \\
(20)\end{array}$ & $\begin{array}{l}145 \pm 12 \\
(29)\end{array}$ & $\begin{array}{l}13 \pm 1 \\
(2)\end{array}$ \\
\hline \multirow{2}{*}{ Exercise } & $\left\{\begin{array}{l}\text { Before } \\
\text { ouabain }\end{array}\right.$ & $\begin{array}{l}29 \pm 4 \\
(10)\end{array}$ & $\begin{array}{l}16 \cdot 6 \pm 3 \cdot 2 \\
(7 \cdot 8)\end{array}$ & $\begin{array}{l}440 \pm 62 \\
(152)\end{array}$ & $\begin{array}{l}\operatorname{I18} \pm 6 \\
(15)\end{array}$ & $\begin{array}{l}39 \pm 6 \\
(16)\end{array}$ & $\begin{array}{l}4 \cdot 5 \pm 0.7 \\
(1 \cdot 6)\end{array}$ & $\begin{array}{l}198 \pm 12 \\
(31)\end{array}$ & $\begin{array}{l}108 \pm 7 \\
(18)\end{array}$ & $\begin{array}{l}149 \pm \mathrm{II} \\
(28)\end{array}$ & $\begin{array}{l}173 \pm 12 \\
(30)\end{array}$ & $\begin{array}{l}47 \pm 6 \\
(14)\end{array}$ \\
\hline & $\left\{\begin{array}{c}\text { After } \\
\text { ouabain }\end{array}\right.$ & $\begin{array}{l}29 \pm 3 \\
(7)\end{array}$ & $\begin{array}{l}15.9 \pm 2.9 \\
(7 \cdot 2)\end{array}$ & $\begin{array}{l}462 \pm 68 \\
(167)\end{array}$ & $\begin{array}{l}\text { I } 77 \pm 6 \\
(\text { I4) }\end{array}$ & $\begin{array}{l}44 \pm 7^{\star} \\
(\mathrm{I} 6)\end{array}$ & $\begin{array}{l}5 \cdot 1 \pm 0.7 \ddagger \\
(x \cdot 7)\end{array}$ & $\begin{array}{l}193 \pm 13 \\
(31)\end{array}$ & $\begin{array}{l}\text { IOI } \pm 5 \\
\text { (II) }\end{array}$ & $\begin{array}{l}142 \pm 9 \\
(23)\end{array}$ & $\begin{array}{l}168 \pm 11 \\
(27)\end{array}$ & $\begin{array}{l}34 \pm 5 t \\
\text { (II) }\end{array}$ \\
\hline
\end{tabular}


(Fig. I). In Cases 4, 5, and 6 the pain progressed to moderate severity only, but in the remainder had reached a severity that required them to stop exercise by the sixth minute. The pain completely receded in all patients after stopping exercise; the average duration of pain after stopping exercise was $293 \mathrm{sec}$ (range 140-540), and the average total duration of pain during the combined exercise and recovery periods was $538 \mathrm{sec}$ (range 345-800).

After intravenous ouabain, Case 3 did not experience any pain at the same level of exercise that in the control study induced severe pain. The remaining 5 patients all experienced some pain during exercise after ouabain; in Cases 2, 4, and 5 the severity of the pain was unchanged, but Cases $I$ and 6 claimed that the intensity of pain was less than in the control study. After ouabain the onset of pain occurred at an average time of $239 \mathrm{sec}$ (range 195-300) after the start of exercise and the average duration of pain after stopping exercise was $137 \mathrm{sec}$ (range 65-280); the total duration of pain was reduced to an average of $258 \mathrm{sec}$ (range 0-545).

Electrocardiographic changes In the control studies at rest the ST segment was isoelectric but during exercise the ST segment was depressed by more than $2 \mathrm{~mm}$ $(\mathbf{P}<0.01)$. After ouabain there was no change in the ST segment at rest, and during exercise the ST segment was depressed to the same degree as in the control studies. There were no changes in the $T$ wave after ouabain either at rest or during exercise.

Changes in heart rate, stroke volume, cardiac output, and systemic arterial pressure $A t$ rest there were no significant

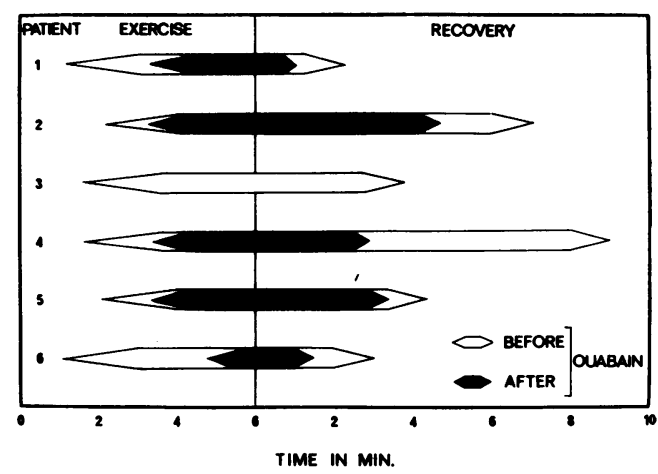

FIG. I Time of onset and duration of pain in patients with angina pectoris before and after acute digitalization with ouabain.

changes in heart rate, stroke volume, cardiac output, or systemic arterial pressure after ouabain (Table).

During exercise there was no significant change in heart rate after ouabain, but the stroke volume $(P<0.05)$ and cardiac output $(P<$ 0.01 ) were both increased (Fig. 2). The mean systemic arterial pressure during exercise was unchanged after ouabain.

\section{Changes in left ventricular performance} At rest there was a consistent and statistically significant increase in left ventricular $\mathrm{dp} / \mathrm{dt}$ $(\max )$ in all patients after ouabain $(P<0.05)$. Mean systolic and end-diastolic pressures, duration of systole and left ventricular minute and stroke work were all unchanged (Table).

\begin{tabular}{|c|c|c|c|c|c|c|c|c|c|}
\hline \multicolumn{2}{|c|}{ Left ventricular work } & \multicolumn{2}{|c|}{ Duration (sec) } & \multirow{2}{*}{$\begin{array}{l}\text { Left } \\
\text { ventricular } \\
d p / d t \\
(\mathrm{~mm} H \mathrm{H} / \mathrm{sec})\end{array}$} & $\begin{array}{l}\text { Blood gas tensions } \\
(\mathrm{mmHg})\end{array}$ & \multirow{2}{*}{$\begin{array}{l}a-A \\
\text { gradient } \\
(m m H g)\end{array}$} & \multicolumn{3}{|c|}{ Electrocardiograph } \\
\hline $\begin{array}{l}\text { Minute } \\
\left(\mathrm{kg} \mathrm{m} / \mathrm{m}^{2}\right)\end{array}$ & $\begin{array}{l}\text { Stroke } \\
\left(\mathrm{g} \mathrm{m} / \mathrm{m}^{2}\right)\end{array}$ & Systole & Diastole & & $\mathrm{P}_{\mathrm{a}} \mathrm{O}_{2} \quad \mathrm{P}_{\mathrm{a}} \mathrm{CO}_{2}$ & & $S T(m m)$ & $\begin{array}{l}\Delta S T \\
(m V \sec )\end{array}$ & $\begin{array}{l}T \text { wave } \\
(\mathrm{mm})\end{array}$ \\
\hline
\end{tabular}

\begin{tabular}{|c|c|c|c|c|c|c|c|c|c|c|}
\hline $\begin{array}{l}5.00 \pm 0.68 \\
(1.67) \\
(5.15 \pm 0.75 \\
(1.85)\end{array}$ & $\begin{array}{l}61 \pm 8 \\
(19) \\
64 \pm 9 \\
(22)\end{array}$ & $\begin{array}{l}0.31 \pm 0.01 \\
(0.02) \\
0.29 \pm 0.01 \\
(0.02)\end{array}$ & $\begin{array}{l}0.44 \pm 0.03 \\
(0.08) \\
0.46 \pm 0.02 \\
(0.05)\end{array}$ & $\begin{array}{l}2260 \pm 140 \\
(350) \\
3110 \pm 290^{\star} \\
(720)\end{array}$ & $\begin{array}{l}69 \pm 4 \\
(9) \\
70 \pm 3 \\
(8)\end{array}$ & $\begin{array}{l}37 \pm 2 \\
(4) \\
38 \pm 2 \\
(5)\end{array}$ & $\begin{array}{l}39 \pm 4 \\
(9) \\
37 \pm 4 \\
(10)\end{array}$ & $\begin{array}{l}0.2 \pm 0.2 \\
(0.4) \\
0.2 \pm 0.2 \\
(0.06)\end{array}$ & $\begin{array}{l}2 \cdot 5 \pm 2 \cdot 5 \\
(6 \cdot 2) \\
2 \cdot 1 \pm 2 \cdot 1 \\
(5 \cdot 2)\end{array}$ & $\begin{array}{l}3 \cdot 9 \pm 1 \cdot 2 \\
(2 \cdot 8) \\
3 \cdot 0 \pm 0 \cdot 9 \\
(2 \cdot 2)\end{array}$ \\
\hline $\begin{array}{l}8 \cdot 03 \pm I \cdot 32 \\
(3 \cdot 23) \\
9 \cdot 84 \pm I \cdot 72^{\star} \\
(4 \cdot 20)\end{array}$ & $\begin{array}{l}70 \pm 12 \\
(30) \\
85 \pm 16 \star \\
(39)\end{array}$ & $\begin{array}{l}0.26 \pm 0.01 \\
(0.03) \\
0.26 \pm 0.01 \\
(0.02)\end{array}$ & $\begin{array}{l}0.26 \pm 0.01 \\
(0.04) \\
0.27 \pm 0.02 \\
(0.05)\end{array}$ & $\begin{array}{l}3200 \pm 290 \\
(710) \\
4200 \pm 310 \ddagger \\
(750)\end{array}$ & $\begin{array}{l}86 \pm 5 \\
(13) \\
93 \pm 5 \\
(13)\end{array}$ & $\begin{array}{l}38 \pm 2 \\
(6) \\
38 \pm 2 \\
(6)\end{array}$ & $\begin{array}{l}28 \pm 3 \\
(8) \\
23 \pm 5 \\
(12)\end{array}$ & $\begin{array}{l}2 \cdot 2 \pm 0.6 \\
(1 \cdot 4) \\
2 \cdot 5 \pm 0.8 \\
(2 \cdot 0)\end{array}$ & $\begin{array}{l}23.7 \pm 6.9 \\
(16.8) \\
19 \cdot 2 \pm 6.2 \\
(15.1)\end{array}$ & $\begin{array}{l}3 \cdot 0 \pm 0.8 \\
(I \cdot 9) \\
2 \cdot 2 \pm 0.5 \\
(I \cdot 2)\end{array}$ \\
\hline
\end{tabular}


During exercise there was a significant increase in left ventricular $\mathrm{dp} / \mathrm{dt}(\max )(\mathbf{P}<0.0 \mathrm{r})$ and left ventricular minute $(P<0.05)$ and stroke work $(P<0.05)$ and a reduction in left ventricular end-diastolic pressure $(P<0.02)$ (Fig. 2). Mean systolic pressure and duration of systole were unchanged.

There was a shift to the left, at the same heart rates, in the relation between left ventricular end-diastolic pressure and stroke work output during exercise after ouabain (Fig. 3).

Respiratory changes There was no significant change in respiratory rate, minute ventilation, alveolar-arterial oxygen tension gradient, or systemic arterial blood oxygen tensions either at rest or during exercise after ouabain (Table).

\section{Discussion}

These studies clearly show that the onset of anginal pain during exercise in each of these patients was accompanied by unequivocal haemodynamic evidence of depressed left ventricular function and that acute digitalization with ouabain significantly improved pumping function of the heart without aggravation of pain.

Though this study was not specifically designed to examine the symptomatic effects of digitalization, it should be noted that no patient noticed an increase in pain in spite of the increase in left ventricular activity. Previous reports have likewise found no consistent change in anginal pain after acute or chronic digitalization (Fenn and Gilbert, 1932; Edens, 1934; Gold et al., 1938; Freedberg, Riseman, and Spiegl, I94I ; Malmborg, 1965; Smith, Bousvaros, and McGregor, 1966; Parker et al., 1969).

The absence of changes in the electrocardiogram also deserves further comment. The digitalis glycosides frequently induce ST segment depression during exercise in normal subjects (Liebow and Feil, I94I; Lepeschkin and Surawicz, 1958; Kawai and Hultgren, 1964), though this is probably not due to myocardial ischaemia (Kawai and Hultgren, 1964). The absence of additional ST depression during exercise in anginal patients after digitalization in these and other studies (Hausner and Scherf, 1933) may thus imply that the direct effect of the drug on the ST segment has been offset by a reduction in the degree of myocardial ischaemia. The haemodynamic arguments in support of this reasoning will next be considered.

The haemodynamic effects of digitalis on the left ventricular function of these patients are of considerable physiological interest and
CHANGes at REST AND DURING EXERCISE AFTER OUABAIN IN PATIENTS WITH ANGINA PECTORIS
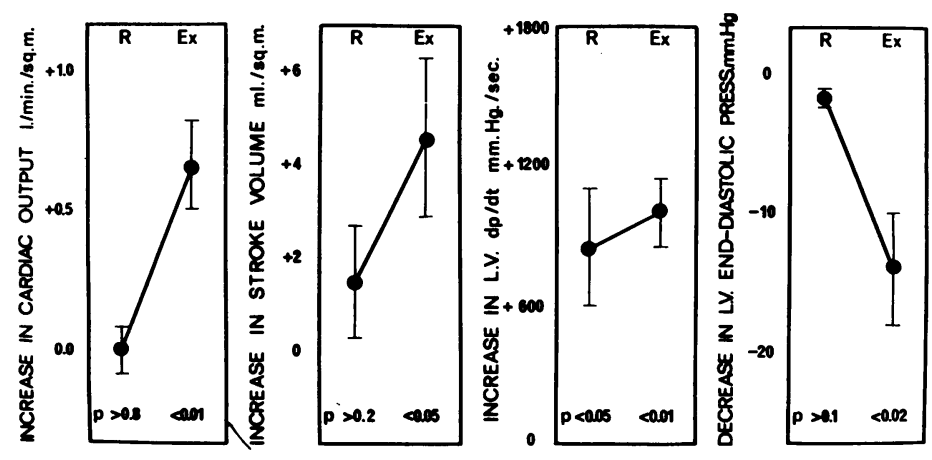

FIG. 2 Haemodynamic changes at rest and during exercise after ouabain in patients with angina pectoris.

therapeutic importance. The digitalis glycosides increase contractility both in the normal (Cotten and Stopp, I958; Braunwald et al., 196I ; Weissler et al., r964; Sonnenblick et al., 1966) and in the failing heart (Stead, Warren, and Brannon, 1948; Bing et al., 1950; Dresdale et al., 1959). In the normal heart their most conspicuous effect is to increase the speed of ventricular contraction ( $\mathrm{LV} \mathrm{dp} / \mathrm{dt}$ max) without change in the normal end-diastolic pressure or cardiac output (Mason and Braunwald, 1963). In the failing heart, however, the positive inotropic action of these drugs is apparent not only in an increase in the velocity of ventricular contraction, but also the translation of the increased contractility into an increase in cardiac output.

The patient with uncomplicated angina pectoris, in whom the heart is normal at rest but suffers acute failure during exercise, thus provides a unique opportunity for the demonstration of these important therapeutic properties of the digitalis glycosides. In the present studies all patients had normal left ventricular function at rest and the only haemodynamic change produced by ouabain was an increase in left ventricular dp/dt (max). However, the seriously depressed left ventricular performance displayed by these patients during the increased work of exercise was significantly improved by ouabain. This was seen not only in the increased velocity of ventricular contraction, the reduction in end-diastolic pressure, and the improved left ventricular function curve, but also by the translation of these primary changes in myocardial contractility into an increase in cardiac output. Though 


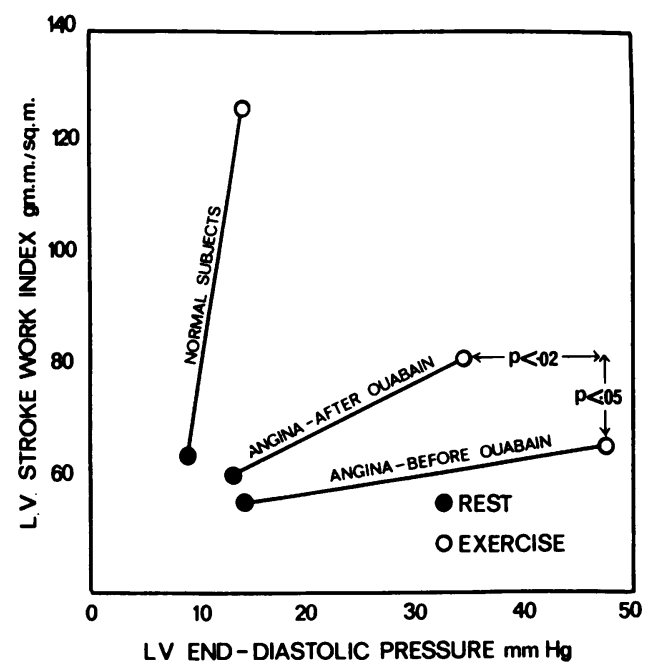

FIG. 3 Effect of acute digitalization with ouabain on the Starling relation between left ventricular stroke work and end-diastolic pressure at rest and during exercise in patients with angina pectoris. Results in normal subjects studied under similar conditions (Sharma and Taylor, 1970) are illustrated for comparison. Values are averaged for each group and probability of significance of change given.

arguments have been advanced that the positive inotropic effect of the digitalis glycosides may be negated by myocardial hypoxia (Wollenberger, 1949), the direct experiments of Sarnoff et al. (1964) have shown conclusively that these drugs improve ventricular contractility in the heart rendered ischaemic by experimental coronary insufficiency, and that this is accomplished without further increase in myocardial oxygen consumption. The present haemodynamic studies confirm these animal experiments.

The digitalis glycosides increase myocardial oxygen consumption in the normal heart by increasing peripheral resistance (Braunwald et al., 196I), systemic arterial pressure (Mason and Braunwald, 1964), and velocity of ventricular contraction (Mason and Braunwald, 1963). Myocardial oxygen consumption is more related to the type than to the amount of work as calculated by conventional formulae. Changes in cardiac output are associated with relatively small changes in myocardial oxygen consumption, but myocardial oxygen consumption is conspicuously influenced by changes in aortic pressure (Gerola, Feinberg, and Katz, 1957; Sarnoff et al., 1958). In the present studies there was no change in aortic pressure associated with the increase in cardiac output after ouabain, and heart rate, another important correlate of myocardial oxygen uptake, was also unchanged. With the aortic pressure and heart rate unchanged, the decrease in left ventricular end-diastolic pressure after ouabain must have been associated with a reduction in left ventricular wall tension, if changes in end-diastolic pressure reflect similar directional changes in end-diastolic volume (Laplace theorem) (Laplace, I84I; Woods, I892; Burch, 1955; Burton, 1957). Sincemyocardial fibre tension is directly related to myocardial oxygen consumption (Sarnoff $e t$ al., 1958; Rodbard, Williams, and Williams, 1959; Monroe and French, 196I; Rodbard et al., 1964), the reduction in myocardial oxygen consumption associated with the decrease in intramyocardial tension after ouabain probably masked the augmentation of oxygen consumption resulting from the increased velocity of myocardial fibre shortening (Sonnenblick et al., 1965). This contention is supported by the observation of Welch et al. (I958) that inotropic agents reduce pressure work efficiency of the normal heart but actually increase overall efficiency, i.e. reduce myocardial oxygen consumption, in the failing heart by reduction of the end-diastolic pressure. The lack of any aggravation of symptoms and the absence of electrocardiographic deterioration in these patients are compatible with this reasoning.

The clinical and therapeutic implications of these findings are worthy of comment. The ischaemic ventricle abruptly fails when subjected to the increased stress of exercise. These studies have shown that left ventricular performance in these patients can be significantly improved by the digitalis glycosides without aggravation of their symptoms or further deterioration in the electrocardiogram. While digitalis may have no place alone in the symptomatic treatment of angina, these studies suggest that the drug may beneficially complement treatment with the adrenergic betareceptor blocking drugs, particularly as these latter agents have conspicuous negative inotropic effects, due to their sympathetic blocking activity. The combined use of these drugs thus affords further opportunity in the rational treatment of patients with angina pectoris.

We wish to thank the many physicians and surgeons who referred patients to us; Sisters F. Ellis and R. Cox and the nursing staff of the Medical Professorial Unit, The General Infirmary, Leeds, for their help and co-operation; Mr. Stafford and the technicians of the Cardiovascular Unit without whose valuable assistance this work would not 
have been possible; the Catheter Room nurses who afforded such essential help; Professor R. J. Linden for his help and encouragement throughout. B. S. and M. K. M. are Senior Ciba Research Fellows, P. A. M. is a Senior Wellcome Foundation Research Fellow.

This work was assisted by a grant from the Wellcome Foundation.

\section{References}

Bing, R. J., Maraist, F. M., Dammann, J. F., Draper, A., Heimbecker, R., Daley, R., Gerard, R., and Calazel, P. (1950). Effect of Strophanthus on coronary blood flow and cardiac oxygen consumption of normal and failing human hearts. Circulation, 2, 513.

Braunwald, E., Bloodwell, R. D., Goldberg, L. I., and Morrow, A. G. (I96I). Studies on digitalis. IV. Observations in man on the effects of digitalis preparations on the contractility of the non-failing heart and on total vascular resistance. fournal of Clinical Investigation, 40, 52.

Burch, G. E. (1955). Theoretic considerations of the time course of pressure developed and volume ejected by the normal and dilated left ventricle during systole. American Heart fournal, 50, 352.

Burton, A. C. (1957). The importance of the shape and size of the heart. American Heart fournal, 54, 801.

Cohen, L. S., Elliott, W. C., Rolett, E. L., and Gorlin, R. (1965). Hemodynamic studies during angina pectoris. Circulation, 3I, 409.

Cotten, M. de V., and Stopp, P. E. (1958). Action of digitalis on the non-failing heart of the dog. American fournal of Physiology, 192, 114.

Dexter, L., Whittenberger, J. L., Haynes, F. W. Goodale, W. T., Gorlin, R., and Sawyer, C. G. (195I). Effect of exercise on circulatory dynamics of normal individuals. Fournal of Applied Physiology, 3, 439.

Dimond, E. G., and Benchimol, A. (1963). Correlation of intracardiac pressure and praecordial movement in ischaemic heart disease. British Heart fournal, $25,389$.

Dresdale, D. T., Yuceoglu, Y. Z., Michtom, R. J., Schultz, M., and Lunger, M. (1959). Effect of lanatoside $C$ on cardiovascular haemodynamics; acute digitalizing doses in subjects with normal hearts and with heart disease without failure. American fournal of Cardiology, $4,88$.

Edens, E. (1934). Die Strophanthinbehandlung der Angina Pectoris. Münchener medizinische Wochenschrift, 81, 1424 .

Fenn, G. K., and Gilbert, N. C. (1932). Anginal pain as a result of digitalis administration. Fournal of the American Medical Association, 98, 99.

Fisher, R. A. (1946). Statistical Methods for Research Workers, Ioth ed. Oliver and Boyd, Edinburgh.

Freedberg, A. S., Riseman, J. E. F., and Spiegl, E. D. (194I). Objective evidence of the efficacy of medicinal therapy in angina pectoris. American Heart fournal, 22, 494.

Gerola, A., Feinberg, H., and Katz, L. N. (1957). The oxygen cost of cardiac haemodynamic activity. Physiologist, 1, 31 .

Gold, H., Otto, H., Kwit, N. T., and Satchwell, H. (1938). Does digitalis influence the course of cardiac pain? Study of 120 selected cases of angina pectoris. Fournal of the American Medical Association, I10, 859.

Goodman, L. S., and Gilman, A. Z. (1970). The Pharmacological Basis of Therapeutics, 4th ed. MacMillan, London.
Hausner, E., and Scherf, D. (1933). Uber angina pectoris probleme. Zeitschrift für klinische Medizin, 126, 166.

Kawai, C., and Hultgren, H. N. (1964). The effect of digitalis upon the exercise electrocardiogram. American Heart fournal, 68, 409.

Laplace, P. S. (184I). Mechanique Celeste, Vol. Io.

Lepeschkin, E., and Surawicz, B. (1958). Characteristics of true-positive and false-positive results of electrocardiographic Master two-step exercise tests. New England fournal of Medicine, 258, 5 I I.

Liebow, I. M., and Feil, H. (I94I). Digitalis and the normal work electrocardiogram. American Heart fournal, 22, 683.

McCallister, B. D., Yipintsoi, T., Hallermann, F. J., Wallace, R. B., and Frye, R. L. (1968). Left ventricular performance during mild supine leg exercise in coronary artery disease. Circulation, 37, 922.

Malmborg, R. O. (1965). A clinical and haemodynamic analysis of factors limiting the cardiac performance in patients with coronary heart disease. Acta Medica Scandinavica, 177, Suppl. 426.

Mason, D. T., and Braunwald, E. (I963). Studies on digitalis. IX. Effects of ouabain on the non-failing human heart. Fournal of Clinical Investigation, 42, I 105.

Mason, D. T., and Braunwald, E. (1964). Studies on digitalis. X. Effects of ouabain on forearm vascular resistance and venous tone in normal subjects and in patients in heart failure. Fournal of Clinical Investigation, 43, 532.

Medical Research Council Annual Report 1962-63 (1964). Statement on responsibility in investigations on human subjects. British Medical fournal, 2, 178 .

Messer, J. V., Levine, H. J., Wagman, R. J., and Gorlin, R. (1963). Effect of exercise on cardiac performance in human subjects with coronary artery disease. Circulation, 28, 404.

Monroe, R. G., and French, G. N. (I96I). Left ventricular pressure-volume relationships and myocardial oxygen consumption in the isolated heart. Circulation Research, 9, 362.

Maler, O., and Rorvik, K. (1958). Haemodynamic consequences of coronary heart disease. British Heart fournal, 20, 302.

Ormrod, R. (1968). Medical ethics. British Medical fournal, $2,7$.

Parker, J. O., Di Giorgi, S., and West, R. O. (1966). A haemodynamic study of acute coronary insufficiency precipitated by exercise. American fournal of Cardiology, 17, 470.

Parker, J. O., West, R. O., Ledwich, J. R., and $\mathrm{Di}$ Giorgi, S. (1969). The effect of acute digitalization on the hemodynamic response to exercise in coronary artery disease. Circulation, 40, 452.

Rodbard, S., Williams, C. B., Rodbard, D., and Berglund, E. (1964). Myocardial tension and oxygen uptake. Circulation Research, 14, 139.

Rodbard, S., Williams, F., and Williams, C. (1959). The spherical dynamics of the heart (myocardial tension, oxygen consumption, coronary blood flow and efficiency). American Heart fournal, 57, 348.

Sarnoff, S. J., Braunwald, E., Welch, G. H., Case, R. B., Stainsby, W. N., and Macruz, R. (1958). Haemodynamic determinants of oxygen consumption of the heart with special reference to the tension-time index. American fournal of Physiology, 192, 148.

Sarnoff, S. J., Gilmore, J. P., Wallace, A. G., Skinner, N. S., Mitchell, J. H., and Daggett, W. M. (I964). Effect of acetyl strophanthidin therapy on cardiac dynamics, oxygen consumption and efficiency in the isolated heart with and without hypoxia. American fournal of Medicine, 37, 3. 
Sharma, B., and Taylor, S. H. (1970). Reversible leftventricular failure in angina pectoris. Lancet, 2, 902.

Sheffield, L. T., Holt, J. H., Lester, F. M., Conroy, D. V., and Reeves, T. J. (I969). On-line analysis of the exercise electrocardiogram. Circulation, 40, 935.

Smith, H. J., Bousvaros, G. A., and McGregor, M. (I966). Failure of acute digitalization to influence exercise tolerance in angina pectoris. British Medical fournal, $\mathbf{x}, 1337$.

Sonnenblick, E. H., Ross, J., Covell, J. W., Kaiser, G. A., and Braunwald, E. (1965). Velocity of contraction as a determinant of myocardial oxygen consumption. American fournal of Physiology, 209, 919.

Sonnenblick, E. H., Williams, J. F., Jr., Glick, G. Mason, D. T., and Braunwald, E. (1966). Studies on digitalis. XV. Effects of cardiac glycosides on myocardial force-velocity relations in the nonfailing human heart. Circulation, 34, 532.

Stead, E. A., Warren, J. V., and Brannon, E. S. (1948). Effect of lanatoside $C$ on the circulation of patients with congestive failure. Archives of Internal Medicine, 81, 282.

Taylor, S. H., MacDonald, H. R., Robinson, M. C., and Sapru, R. P. (1967). Computers in cardiovascular investigation. British Heart fournal, 29, 352.
Taylor, S. H., and Sharma, B. (1971). The sequence of haemodynamic effects associated with the onset and resolution of pain in angina pectoris. (In preparation.)

Weissler, A. M., Gamel, W. G., Grode, H. E., Cohen, S., and Schoenfeld, C. D. (1964). The effect of digitalis on ventricular ejection in normal human subjects. Circulation, 29, $72 \mathrm{r}$.

Welch, G. H., Braunwald, E., Case, R. B., and Sarnoff, S. J. (1958). The effect of mephentermine sulphate on myocardial oxygen consumption, myocardial efficiency and peripheral vascular resistance. American fournal of Medicine, 24, 87I.

Wiener, L., Dwyer, E. M., and Cox, J. W. (1968). Left ventricular haemodynamics in exerciseinduced angina pectoris. Circulation, 38, 240.

Wollenberger, A. (1949). The energy metabolism of the failing heart and the metabolic action of the cardiac glycosides. Pharmacological Reviews, I, 3 II.

Woods, R. H. (1892). A few applications of a physical theorem to membranes in the human body in a state of tension. Fournal of Anatomy and Physiology, 26, 362 .

Requests for reprints to Dr. S. H. Taylor, Department of Medicine, The Martin Wing, The General Infirmary, Leeds LSI 3EX. 